\title{
Three case studies: mechanisms other than spillage and leaks that change groundwater quality and inhibit closure certification
}

TL Patterson SLR International, USA

M Trevor SLR International, USA

\begin{abstract}
Baseline groundwater quality at mines is often poor, containing naturally occurring constituents at elevated concentrations. Groundwater quality changes at mine sites during operations and closure, and the changes are typically attributed to releases from mine waste or spillage of process solutions or waste water. If the changes are related to release of mine waste or water, then remediation is required before closure can be certified as complete. However, there is a long list of other mechanisms that can cause groundwater quality changes at mines, ranging from changes to recharge and flow patterns caused by construction to oxidation of minerals in the walls of a monitoring well.
\end{abstract}

This paper presents case studies for two closed gold mines where groundwater quality changes were preventing closure certification and many of the changes were not due to release of mine waste or water. The paper also describes the information developed to demonstrate that the changes were a consequence of constructing and operating the mine and represented a new baseline condition. The paper also describes how anticipation of such changes as part of environmental permitting would help streamline closure, and elaborates on what and where such information should be incorporated in permitting.

Keywords: closure, groundwater monitoring, geochemical changes, impacts

\section{Introduction}

Final closure certification of a mine, or transition from the closure to post-closure phase, often partly depends on acceptance by an environmental regulator that conditions no longer represent a threat to human health or the environment (Sassoon 2008). With regard to surface and groundwater quality conditions, this determination can be made in a variety of ways that are dependent on the regulatory setting and program, but it is often dependent on evaluation of monitoring data gathered during closure. The evaluation may consist of, among other approaches, comparison with baseline (i.e. pre-mine) conditions, comparison with water quality standards, or performing a human health and/or ecological risk assessment. If unacceptable conditions persist, the regulator will usually focus on further reclamation or remediation to reduce impacts from ongoing or historical releases from mine waste or spillage of process solutions or waste water.

Many mineral and metal deposits are located in complex geologic, geochemical and hydrologic settings; for example, sulphide deposits resulting from hydrothermal alteration along fault or fracture zones. Natural weathering processes occurring in these settings can release constituents to surface and groundwater that result in poor baseline water quality (Posey et al. 2000; Runnells et al. 1992) that could represent a threat to human health or the environment (i.e. baseline water quality may exceed regulatory water quality standards or a risk assessment on baseline conditions could identify an unacceptable human health or environmental risk). Construction and operation of a mine will often exacerbate and/or redistribute these conditions by changing site hydrology, groundwater flow and recharge conditions, and exposing fresh mineral surfaces where weathering occurs. Therefore, surface and groundwater quality can change as a 
consequence of constructing and operating a mine, and the water quality changes are not necessarily attributable to releases from mine waste management units or spillage of mine or process water.

Unfortunately, because many of the constituents are naturally occurring in the mineralised zone and country rock, the changes that occur due to releases from mine waste can look a lot like those caused by construction and operation. While releases from mine waste and water should be mitigated to the extent necessary, there is usually very little that can be done about the permanent changes that are caused by construction and operation of the mine. Distinguishing the changes caused by releases from those caused by construction will guide closure strategies, optimise utilisation of resources, and ultimately facilitate certification of closure. In addition, the experiences described herein suggest that incorporating documentation within initial regulatory authorisations of the construction and operation conditions that may change water quality will also facilitate timely and efficient closure.

\section{$2 \quad$ Case studies}

In this paper, we present specific examples encountered at two former gold mines where groundwater quality changes occurred and were preventing certification of closure by the regulator. In each example, the initial supposition was that the water quality change was related to a release of mine waste or mine water. We describe the data that led to alternative hypotheses, the analyses performed to evaluate the alternative hypotheses, and the results and conclusions of the evaluations. This paper also includes recommendations related to technical support and baseline studies performed during the initial regulatory authorisations for a new or proposed mine (i.e. to support an environmental impact statement or environmental impact report) that may help to facilitate timely and efficient closure.

Both of the former gold mines that are the subject of this paper have been in closure for an extended period of time; mining stopped in the early 1990s and neither has produced any gold since approximately 1994. Neither mine operated very long (less than five years each). As of the date of this publication, neither mine is certified as closed, although much progress has been made to resolving closure issues.

\subsection{Case Study 1: Monitoring Well \#2}

The first case study we present is for a monitoring well located at the downgradient toe of a flotation tailings impoundment at the first mine. A plan view of the layout is presented in Figure 1 . The impoundment contains approximately 10 million tonnes of tailings, is approximately 57 hectares (ha) in area, and was constructed in a shallow valley with rockfill embankments at either end. The southern (downstream) embankment is approximately $24 \mathrm{~m}$ high. The impoundment is lined with clay (including the dam face) with a gravel leachate collection system (LCS) between the liner and the tailings; the tailings act as an inner liner. Underneath the liner, there is a groundwater drain and a drainpipe to convey the flows of a spring located under the impoundment. There is also a foundation drain to remove water from the foundation of the embankment.

The tailings are non-acid generating with high neutralisation potential and very low residual sulphide content. Water quality data for the tailings water and drains relevant to this discussion are summarised in Table 1. As indicated by the LCS, water in the tailings impoundment had elevated concentrations of total dissolved solids (TDS) and sulphate, detectable arsenic, and somewhat elevated nitrate. Concentrations of TDS and sulphate were higher towards the end of operations and during closure. Nitrate was lowest at the beginning of operations and generally increased to the end of operations, then was low during the closure period. The foundation drain had very high nitrate concentrations during operations. Elevated nitrate concentrations were attributed to blasting residual (i.e. ammonium nitrate) in the ore and waste rock. The spring drain indicated elevated TDS and arsenic during the pre-mine period, which persisted through operations and closure. 


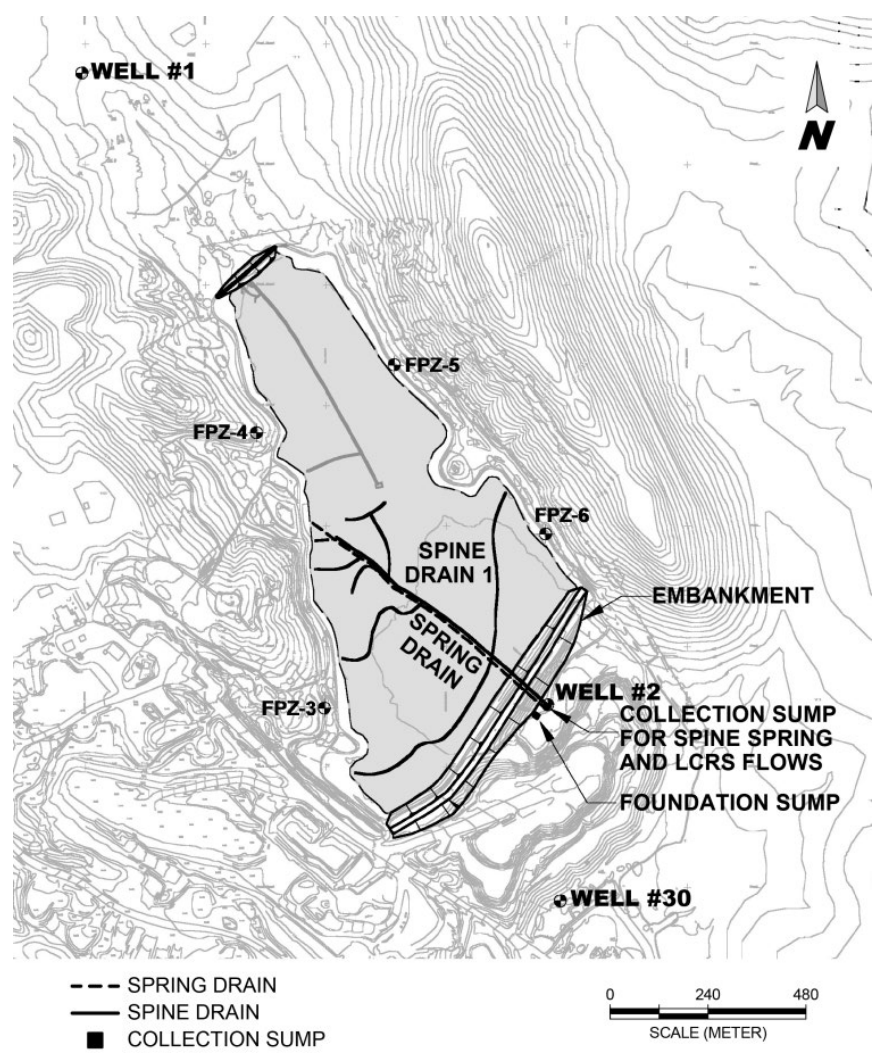

Figure 1 Flotation tailings impoundment and monitoring locations

Table 1 Summary of impoundment drain water quality ( $\mathrm{mg} / \mathrm{L})$

\begin{tabular}{llllll}
\hline Location & Period & $\begin{array}{l}\text { Total dissolved } \\
\text { solids }\end{array}$ & Sulphate & Arsenic & Nitrate \\
\hline \multirow{2}{*}{ LCS } & Operations & $670-4,230$ & $251-1,889$ & $<0.01-0.08$ & $<1-25$ \\
& Closure & $1,540-4,480$ & $290-4,260$ & $<0.001-0.10$ & $<0.1-2.5$ \\
\multirow{2}{*}{ Groundwater } & Operations & $380-2,800$ & $64-959$ & $<0.01-0.22$ & $<1-32$ \\
& Closure & $650-2,470$ & $310-1,340$ & $0.003-0.03$ & $0.6-29$ \\
\multirow{2}{*}{ Spring } & Pre-mine & $2,910-3,680$ & $582-697$ & $<0.01-0.03$ & $<1-2.8$ \\
& Operations & $1,460-4,150$ & $234-1,510$ & $<0.01-0.09$ & $0.2-7.8$ \\
& Closure & $1,210-3,446$ & $270-1,530$ & $<0.01-0.07$ & $0.2-8.3$ \\
\hline \multirow{2}{*}{ Foundation } & Operations & $270-3,060$ & $21-1,766$ & $<0.01-0.06$ & $2.7-560$ \\
& Closure & $490-2,830$ & $270-1,640$ & $<0.002-0.11$ & $<0.1-22$ \\
\hline
\end{tabular}

The locations of monitoring wells \#1 and \#2 are shown in Figure 1. These wells were installed during the baseline period before the impoundment was constructed. There was also limited testing of the spring during the baseline period. Monitoring data were evaluated during the operations and closure periods as required by the environmental permits by comparison to site-specific water quality protection standards (WQPSs) (statistical control limits determined from the baseline dataset). If a WQPS is exceeded, evaluation and corrective action is triggered. The TDS and sulphate concentrations versus time at Well \#2 are plotted in Figure 2. As shown in the figure, both TDS and sulphate began rising early in mine operations (which began in 1989). The concentrations exceeded WQPSs during operations in 1992, which triggered initial evaluation. 


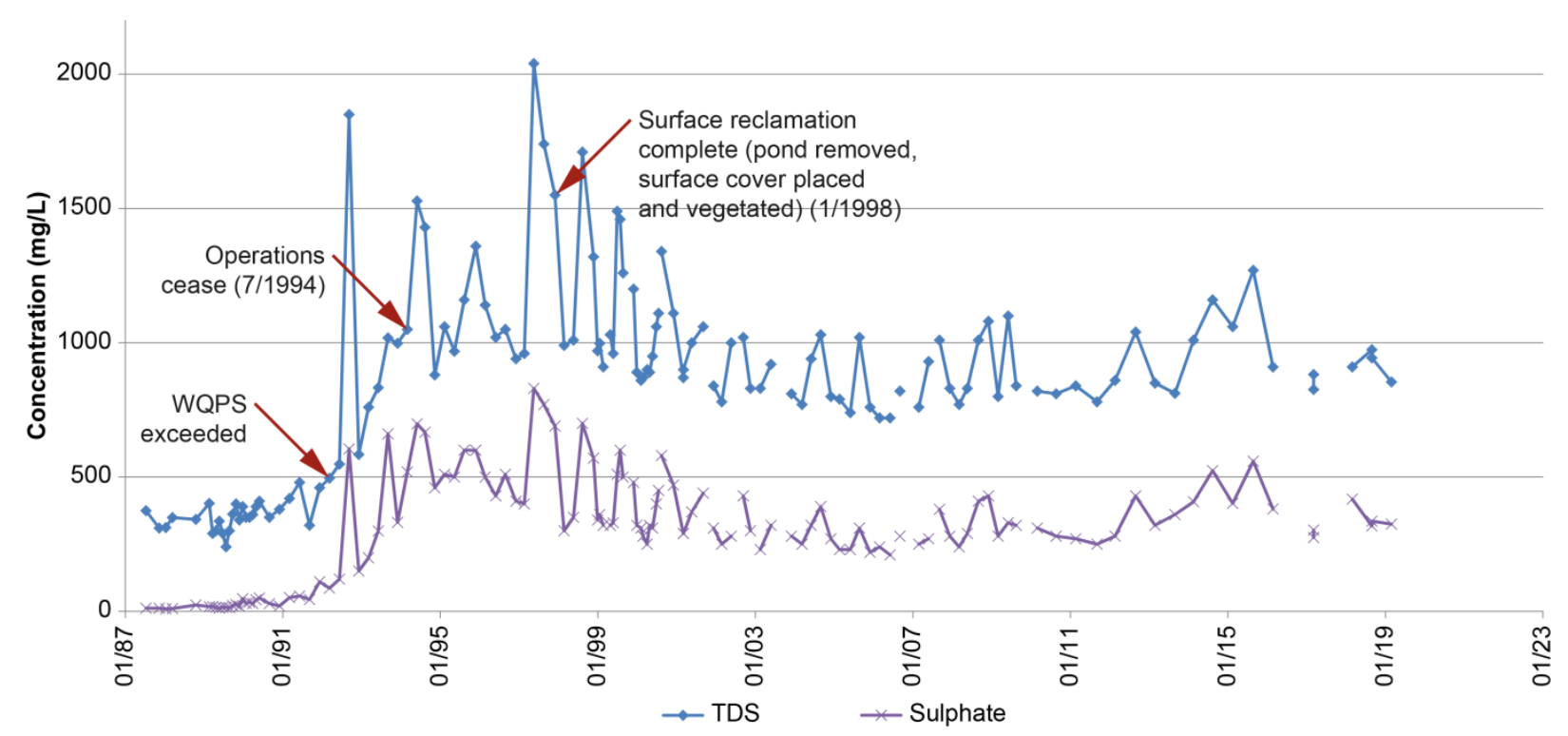

Figure 2 Total dissolved solids (TDS) and sulphate versus time at Well \#2

The initial evaluation, completed in 1993, concluded that the change was due to excess seepage of tailings water through the liner into groundwater. The initial corrective actions developed included reducing the volume of water stored in the unit and closure. The storage volume was addressed within a year, and the mine ceased operating and initiated closure beginning in July 1994. By the end of 1998, the pond on the impoundment had been drained, the surface graded to slope towards a breach in the embankment, and a $15 \mathrm{~cm}$ thick soil cover was constructed and vegetated. As shown in Figure 2, the TDS and sulphate concentrations dropped somewhat after reclamation and seasonal peaks in concentrations were smaller, but the water quality stopped improving by about 2004. Concentrations were still above the WQPSs, thus evaluation of conditions was ongoing throughout and following this period.

In approximately 2002, an alternative hypothesis was being formulated as the cause of water quality changes at Well \#2. The alternative hypothesis had two elements: (1) construction of the impoundment had cut off groundwater recharge within the valley, eliminating the supply of a thin layer of good-quality groundwater near the ground surface; and (2) the embankment, which was constructed with rock mined from the pits, was a primary source of TDS and sulphate. This alternative hypothesis was developed based on observations at Well \#1 and also comparison of the chemistry of drain water with Well \#2 groundwater.

Well \#1 served intermittently as a water supply well for a local rancher in addition to a baseline monitoring well for the mine. The water quality of Well \#1, located upgradient of the flotation tailings impoundment, was good with low TDS and sulphate concentrations. The water quality had remained constant throughout the baseline and operations period. However, the rancher contacted the mine and asked if a new well could be installed because the water quality at Well \#1 had become degraded. Figure 3 presents the concentration trends of several constituents in Well \#1. As shown in the figure, the concentrations increased abruptly in mid-1999. The rancher stopped using the well and the water quality rapidly returned to baseline conditions. He started using the well again and the water quality again became degraded. 


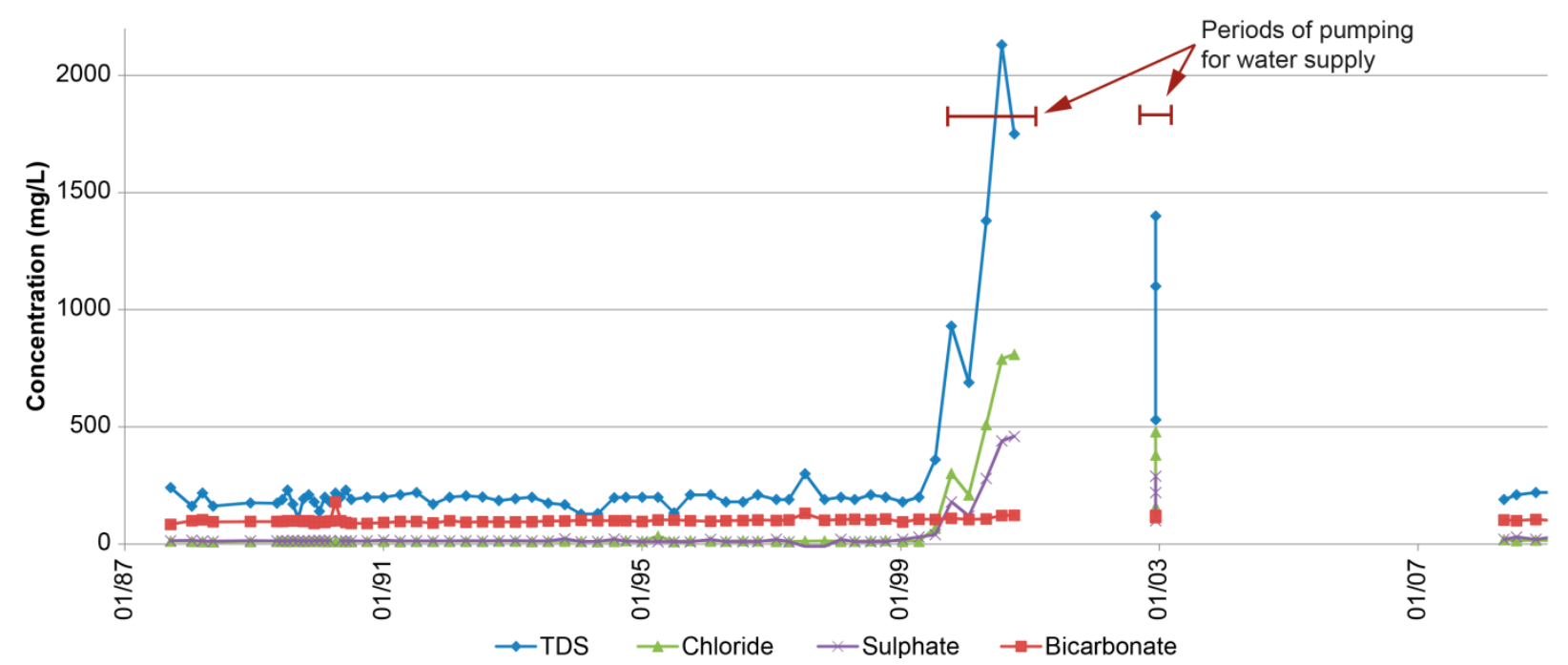

Figure 3 Water quality response in Well \#1

Additional study of the relative abundances of anions and cations showed that the water was not like tailings water from the LCS, but matched the abundances of naturally occurring poor-quality groundwater at the site. Well \#1 was completed in a metavolcanic formation that has typically good groundwater, but the geochemical fingerprint was more like the poor-quality water characteristic of an adjacent metasediment formation. This led to a field study near Well \#1 where a borehole was advanced and used to develop a vertical profile of groundwater chemistry. The results of the vertical profiling revealed that there was a shallow layer approximately 10 meters thick that had good-quality groundwater with chemistry typical of the metavolcanics, but that the chemistry of deeper water was characteristic of the metasediments even though the lithology remained metavolcanic.

A new conceptual hydrogeological model was developed based on the additional study. Before mining, a relatively thin lens of good-quality groundwater was present as a result of infiltrating surface water and rainfall in the valley where the tailings impoundment was constructed. Underlying this layer was poorer quality water that had migrated from the metasedimentary formation at higher elevations to the west (which was also the source of the spring drained by the spring drain). When the liner system for the tailings impoundment was built, the source for the lens of good-quality water was cut off but migration of poorquality groundwater from the west continued. Well \#2 was monitoring the lens of good-quality water during the baseline period, but the lens disappeared shortly after construction of the impoundment and the well was monitoring the poorer water migrating from the west.

Comparison of the water chemistry of the degraded water at Well \#2 with the chemistry of the spring drain indicated, however, that groundwater at Well \#2 was not entirely like the metasedimentary water coming out of the spring drain. There was a higher proportion of sulphate at Well \#2, a lower proportion of chloride, no arsenic, and a significantly higher nitrate concentration. The regulatory agency believed the additional source of dissolved constituents at Well \#2 was seepage from the tailings impoundment.

The approach to demonstrating the source was not the tailings impoundment was principally evaluation of water quality data. Figure 4 shows concentration of nitrate over time in Well \#2, the LCS, and the foundation drain (note the log scale of the vertical axis). The nitrate concentration was high in Well \#2 and often higher than nitrate in the tailings water (as indicated by the LCS). In fact, the only location being monitored at this mine with nitrate concentrations higher than Well \#2 was the foundation drain. As mentioned previously, the foundation drain drained the foundation of the embankment for the tailings impoundment, which is located just upgradient of Well \#2 (Figure 1). 


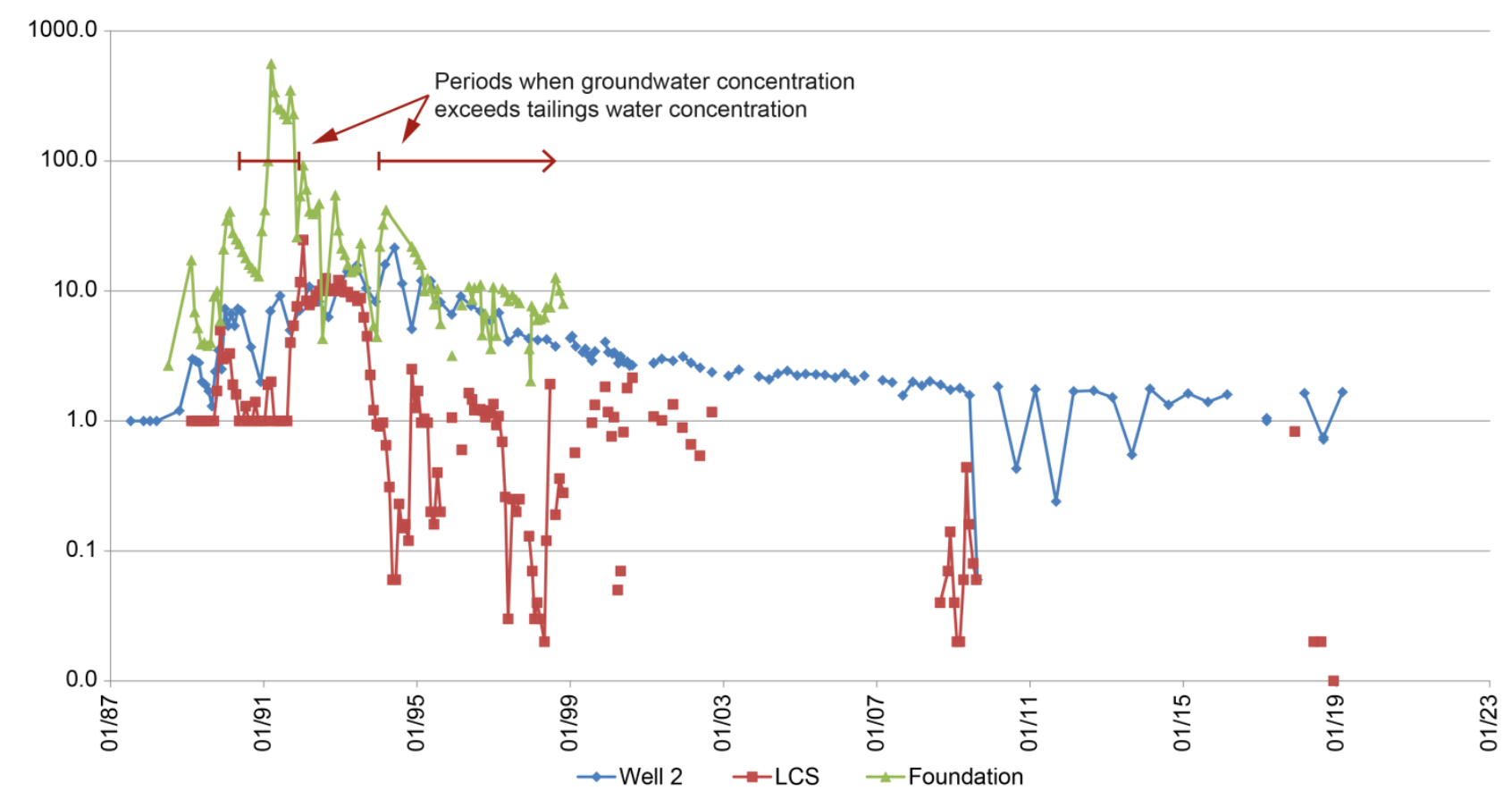

Figure 4 Nitrate versus time at Well \#2 and select drains

The embankment for the tailings impoundment was constructed of rock mined from the open pits (i.e. it was the same as the rock in the waste rock piles). Leachate from the waste dumps at this mine had elevated nitrate and sulphate concentrations. The source of the nitrate is believed to be residue from blasting and the source of the sulphate is oxidation of sulphide in the waste rock.

The embankment rock was screened of fine material so that it would be free-draining. The very high nitrate concentrations observed in the foundation drain occurred during the wet season (Figure 4) and are presumed to be a result of infiltrating precipitation rapidly rinsing the nitrate out of the embankment and into the drain. In a few years, most of the nitrate had been washed out of the embankment and the concentrations decreased. The nitrate trend in Well \#2 was generally the same as that of the foundation drain, although concentrations were lower.

Sulphate showed a similar pattern of variation in the foundation drain, with peak concentrations occurring during the wet season. However, as the sulphate was being continuously generated by sulphide oxidation in the embankment rock, the sulphate concentration in foundation drain water never dropped (Table 1). As shown in Figure 2, the sulphate concentration at Well \#2 also exhibited a wintertime peak, and while the concentration dropped somewhat after closure, it has never returned to the pre-mine baseline levels.

Ultimately, the regulator accepted that the water quality change was not due to a release of tailings water. A closure permit for the impoundment was issued with updated WQPSs based on the stabilised conditions at Well \#2 and other locations. While it was not the best situation to have the embankment constructed of the same material that had been placed in waste piles that were producing leachate with high TDS and sulphate, the water quality at Well \#2 was actually similar to baseline conditions at other wells around the mine and there was no impairment to the environment caused by the higher TDS and sulphate concentrations.

\subsection{Case Study 2: Monitoring Well \#12}

The second case study is for monitoring Well \#12 at the same mine located near a diverted stream and one of the mine pits. A plan view of the area with current groundwater elevation contours is presented in Figure 5. The issue at Well \#12 was principally the arsenic concentration, although there were several other constituents being monitored that exhibited a similar pattern. The arsenic concentration trend at Well \#12 is shown in Figure 6 along with the groundwater elevation at Well \#12 and the pit lake level. 


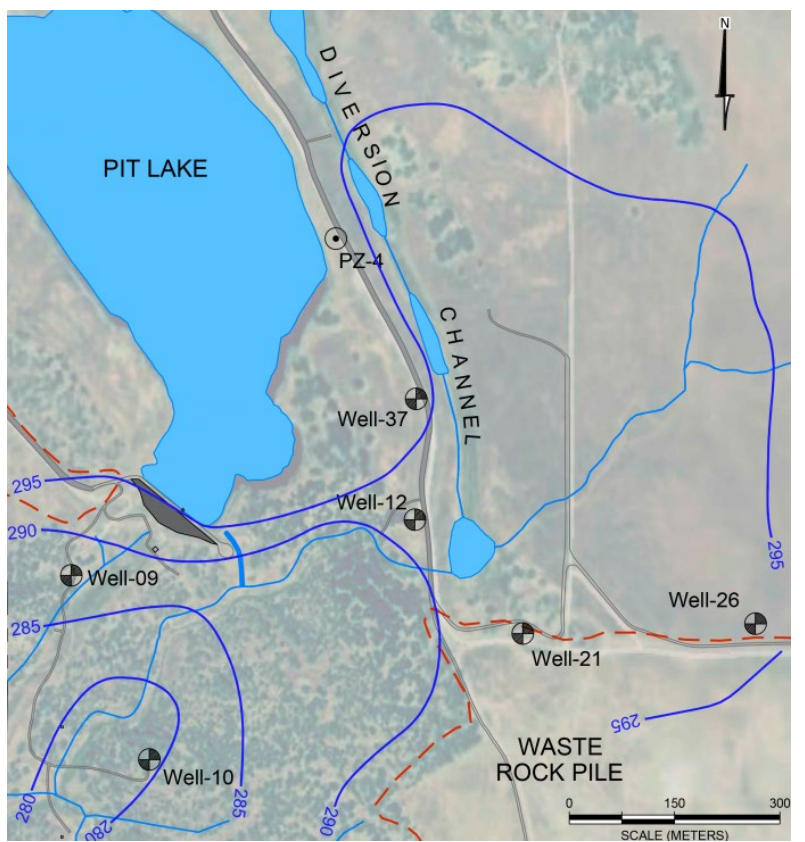

Figure 5 Current groundwater elevation contours

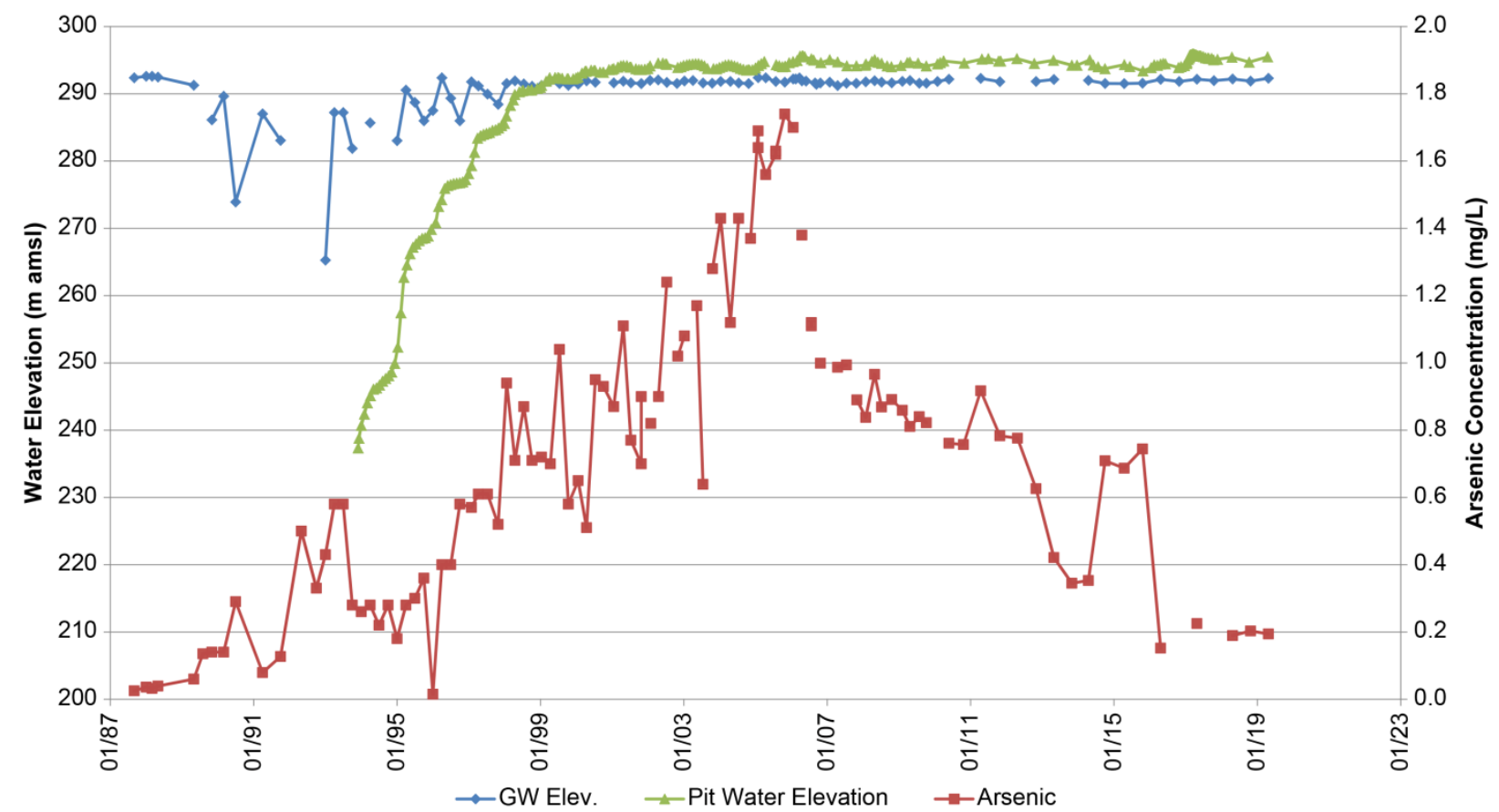

Figure 6 Arsenic concentration at Well \#12 versus time

Well \#12 is approximately $31 \mathrm{~m}$ deep, and the screened interval crosses a portion of the mineralised zone, as indicated by quartz veining and other evidence of hydrothermal alteration (pyrite, chlorite, sericite, mariposite), with the host rock being the metavolcanics mentioned under Case Study 1. The well was installed during the baseline period. There are no mine waste management units (waste rock piles, tailings impoundments, process water ponds, etc.) upgradient of or near Well \#12. However, during post-closure, the well is used to monitor seepage from the pit lake.

Being completed in the metavolcanics, the baseline water quality was relatively good for a well that crossed the mineralised zone. Baseline arsenic concentrations ranged from 0.025 to $0.04 \mathrm{mg} / \mathrm{L}$; TDS and sulphate were 760 to $1,620 \mathrm{mg} / \mathrm{L}$ and 93 to $230 \mathrm{mg} / \mathrm{L}$, respectively. These baseline concentrations were used to develop the WQPSs. As shown in Figure 6, the WQPS of $0.046 \mathrm{mg} / \mathrm{L}$ for arsenic was exceeded during the 
first year of mining (1989) and the arsenic concentration kept climbing to a peak in 2004 that was approximately 40 times higher than the baseline concentrations. The regulatory agency required an investigation as to why this change occurred. However, because there were no mine wastes being managed nearby or upgradient, there was no possibility that it was due to spillage or a release of mine waste.

The diversion of an ephemeral stream along with dewatering of the pit were ultimately identified as key causes of the water quality changes. Prior to mining, the ephemeral stream ran through the area of the mine pit (Figure 7). Early in the construction phase, the stream was diverted around the area of the future pit, which resulted in it flowing much closer to Well \#12. Excavation of the mine pit began in early 1989, and because of shallow groundwater in this area, dewatering of the pit began approximately the same time. Mining was completed in March 1994, and the pit was allowed to fill with water. Filling was largely complete by 2000 .

Figures 7 and 8 show the interpreted groundwater level conditions for pre-mine conditions and at maximum mine depth. These figures along with Figure 5 indicate how the direction of groundwater flow changed because of mine construction. The ephemeral stream flows only during the wet season, although some reaches near the well remain wet all year round. With the original alignment during the baseline period, there was no surface water near Well \#12 and groundwater generally flowed westward in the vicinity of the well.

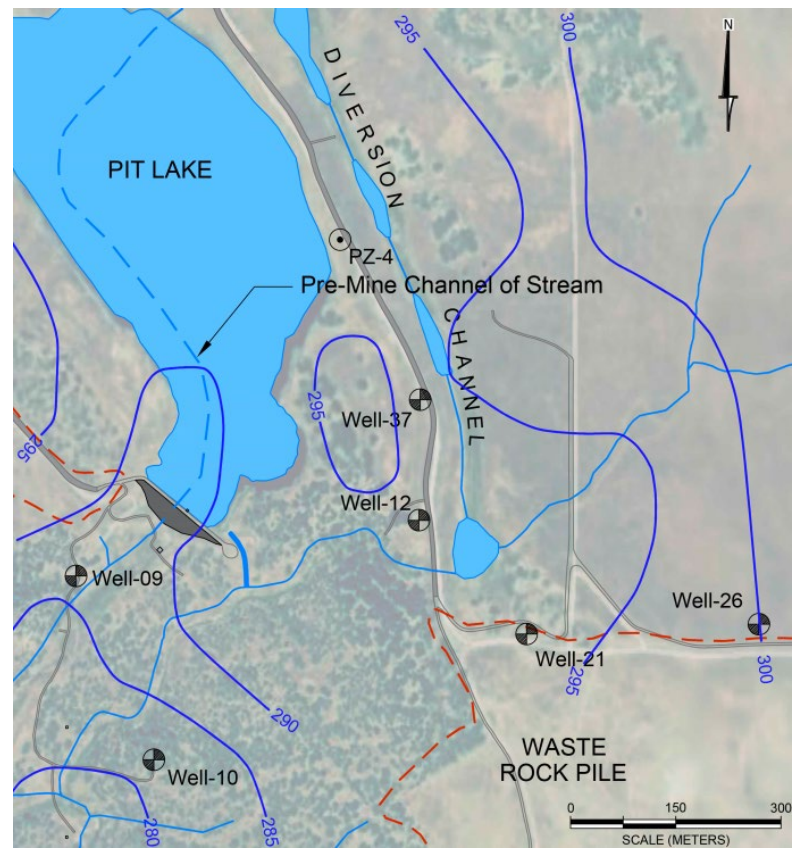

Figure 7 Interpreted groundwater level conditions for pre-mine conditions

When the stream was diverted, the diversion channel acted as a source of groundwater recharge in the vicinity of Well \#12. Based on the observation of mineralised rock in the boring log for Well \#12, the initially relatively small changes in arsenic concentration were attributed to the new recharge flushing arsenic from previously unsaturated mineralised bedrock into groundwater. 


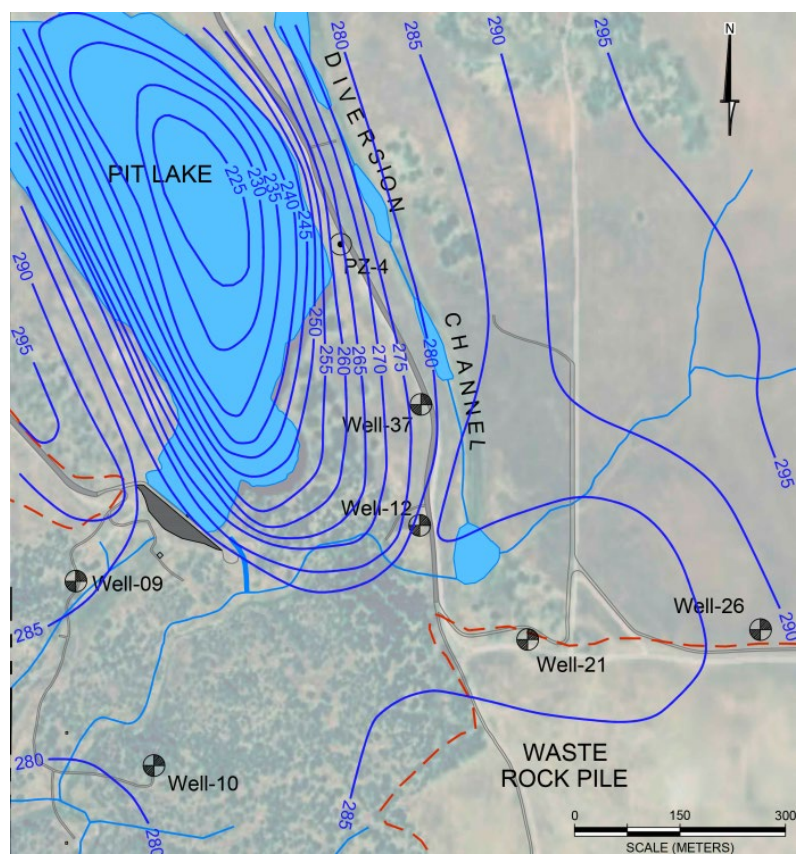

Figure 8 Interpreted groundwater level conditions at maximum mine depth

In subsequent years, the pit was mined to a depth of approximately $110 \mathrm{~m}$. As shown in Figure 8 , the excavation and dewatering of the pit significantly lowered groundwater levels and changed the direction of flow at Well \#12 from westward to northwestward.

The hydrograph for Well \#12 in Figure 6 shows that, during the period of mining, the groundwater elevation was fluctuating seasonally over a wide range (up to 15 to $20 \mathrm{~m}$ ) and this is attributed to a hydraulic connection between the pit and groundwater in the area of Well \#12. This large fluctuation in water level resulted in a condition that could be considered a large-scale in situ humidity cell, with alternating wet and dry oxidising conditions. Like a humidity cell, the conditions were optimal for increased sulphide oxidation. The oxidation of pyrite and arsenopyrite (which occurs in the mineralised zone) resulted in increasingly high concentrations of arsenic and sulphate in this area.

Mining ended in 1994, and the pit began filling with groundwater. As shown in Figure 6, the range over which groundwater levels fluctuated decreased during this period until the pit water level rose above the groundwater at the end of 1998, and then stabilised at the beginning of 2000 . Thus, after 1998 , the hydraulic gradient was from the pit towards Well \#12 and the creek. The arsenic concentration continued to increase during this period. The concentration peaked in 2004 and then began decreasing.

The arsenic concentration of the pit lake ranges from 0.06 to $0.13 \mathrm{mg} / \mathrm{L}$, so it is much lower than the concentration of groundwater at Well \#12. As shown in Figure 6, the decreasing groundwater concentrations at Well \#12 are approaching the pit lake levels. Figure 9 shows the trend in sulphate concentration at Well \#12 along with the hydrographs of the well and of the pit lake level. The sulphate concentration at Well \#12 increased during the period of mining with wide annual fluctuations, and continued increasing to the present possibly with the concentrations levelling off recently. The sulphate concentration of the pit lake ranges from 1,550 to $1,920 \mathrm{mg} / \mathrm{L}$, which is similar to the recent concentrations at Well \#12. Therefore, the arsenic and sulphate concentration trends and magnitude appear to be consistent with the pit lake water flushing out the high-arsenic groundwater. It also appears that, with more stable water level conditions, the "large-scale in situ humidity cell" no longer exists, which reduces the release of arsenic and sulphate from pyrites in the bedrock. 


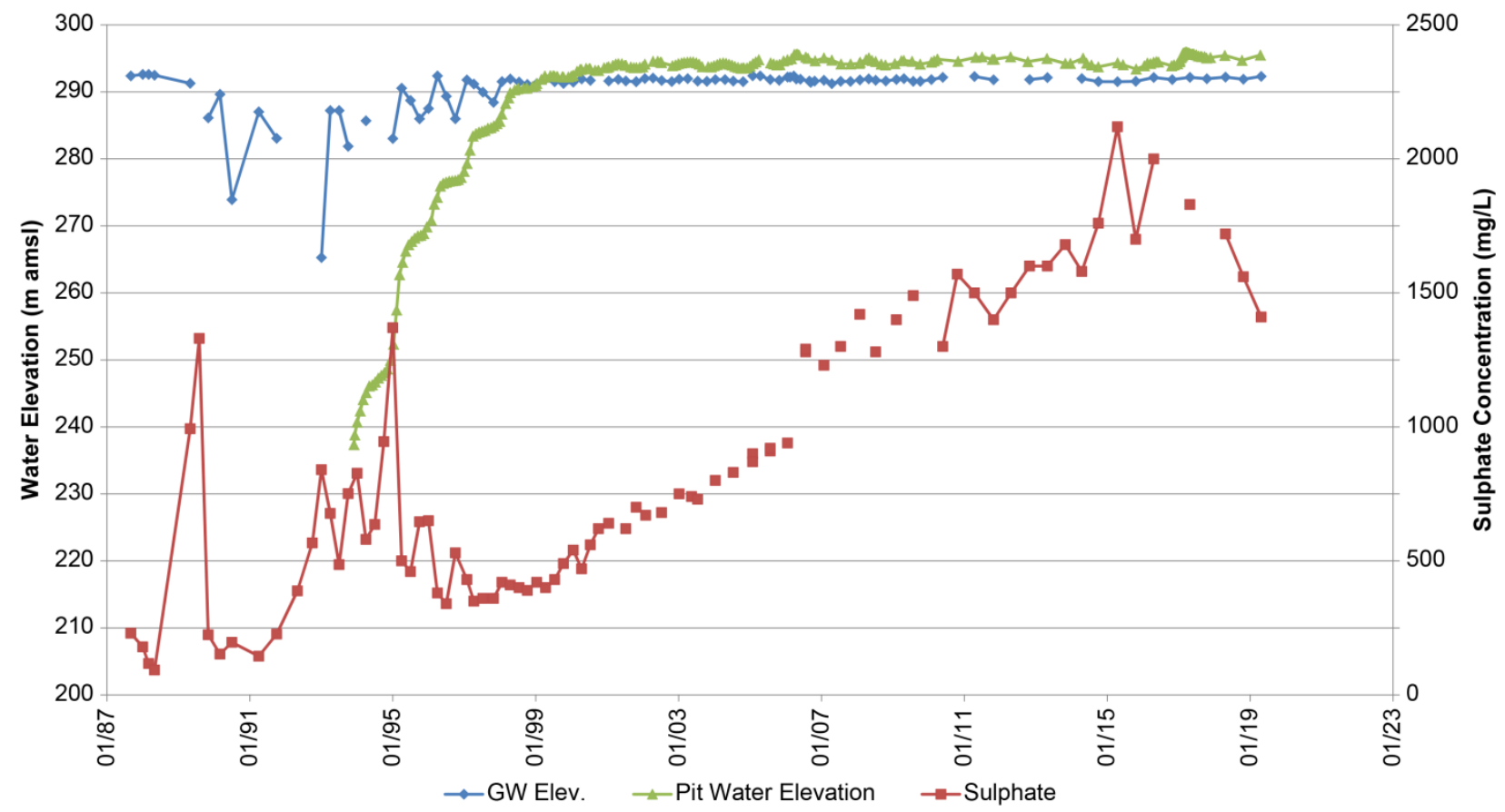

Figure 9 Sulphate concentration at Well \#12

The regulator agrees with the explanations provided above. However, because of the flow of pit water through the ground towards the diversion channel, they want to be sure that pit water does not impact the water quality of the diversion channel.

\subsection{Case Study 3: Monitoring Well \#M-1}

The third case study is for monitoring Well \#M-1 at the second mine. Well \#M-1 was installed in bedrock during the pre-mine period to characterise baseline hydrogeologic and water quality conditions at the mine. During and after mining, the well was used to monitor groundwater conditions downgradient of a heap leach pad constructed within a waste rock pile. The setting for the well is shown in Figure 10.

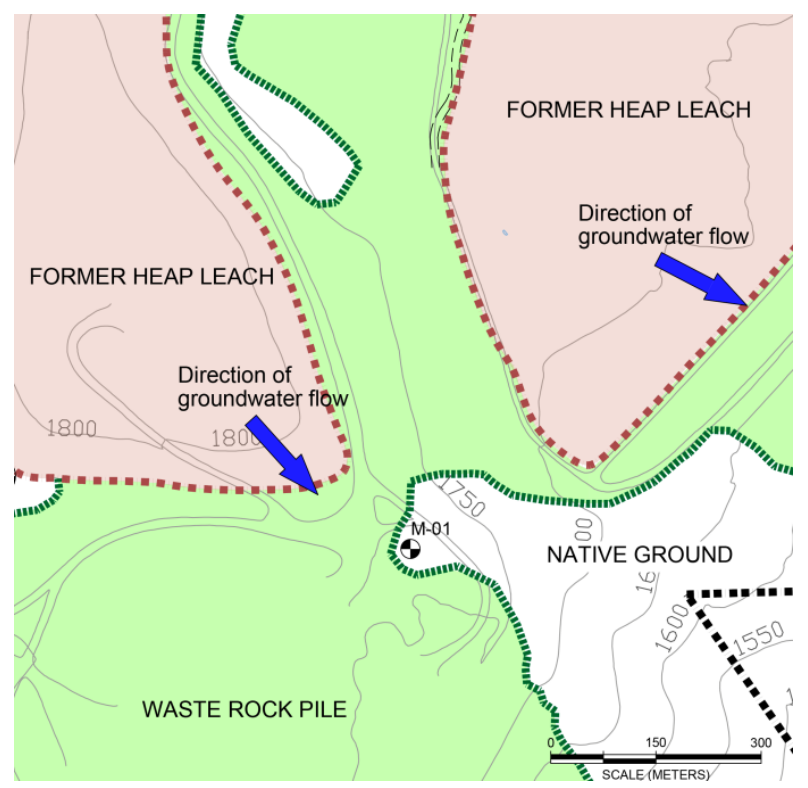

Figure 10 Vicinity location of Well \#M-1

The heap leach and waste rock piles for this mine were constructed off a ridge of bedrock oriented approximately east to west. Well \#M-1 is located south of the ridge. The mineralised zone and open cut are 
located to the northwest of $M-1$, although there is hydrothermally altered bedrock throughout the area. There is extensive quartz veining in localised areas, and pyrite and other hydrothermal alteration minerals (serpentinite, sericite, mariposite) also occur in these areas.

There is almost no soil at the site, so all groundwater occurs in bedrock. All groundwater movement is via fractured flow, and jointing and fracturing is very limited. Typically the greatest flows are in fractures associated with zones of quartz veining. There is very little groundwater at the site; historical mining in the 1930s documented that even though extensive underground workings extended $1,500 \mathrm{~m}$ below the ground surface, the typical dewatering rate for the entire mine was low, on the order of 35 cubic metres per day.

Early in the operation of the modern mine, the operators developed WQPSs for the regulatory monitoring program. The selected approach for WQPSs was based on baseline water quality at two upgradient monitoring wells. However, there were exceptions for specific constituents at selected locations, and selenium at M-1 was one of these exceptions.

During the baseline period (1985), the selenium concentration at M-1 had increased from 8 to $19 \mu \mathrm{g} / \mathrm{L}$. Selenium concentrations at all other monitoring wells at the site ranged from non-detect $(<2 \mu \mathrm{g} / \mathrm{L})$ to $11 \mu \mathrm{g} / \mathrm{L}$ and were stable (not increasing). The selenium WQPS selected for $\mathrm{M}-1$ was $19 \mu \mathrm{g} / \mathrm{L}$; for all other monitoring locations the WQPS was $11 \mu \mathrm{g} / \mathrm{L}$.

Figure 11(a) shows the trend in selenium concentration at M-1 during the baseline (1985), operational (1986-1990), and closure and post-closure periods. Selenium remained below the WQPS throughout the operational period, but started rising in mid-1991 and has remained above the WQPS since that time. As required by the regulatory program, an investigation was initiated to evaluate if the exceedance of the selenium WQPS was due to a release of mine water or waste. The selenium concentrations of heap leach pad and waste rock dump leachate were in the same range as the concentrations at M-1 at the time (i.e. 30 to $60 \mu \mathrm{g} / \mathrm{L}$ ). In addition, the concentrations of mine waste indicator constituents (sulphate from sulphide oxidation, nitrate from blast residue and cyanide degradation, and total cyanide from leaching operations) had all increased in M-1 at about the same time as the selenium concentration (Figures 11(b) to 11(d)).

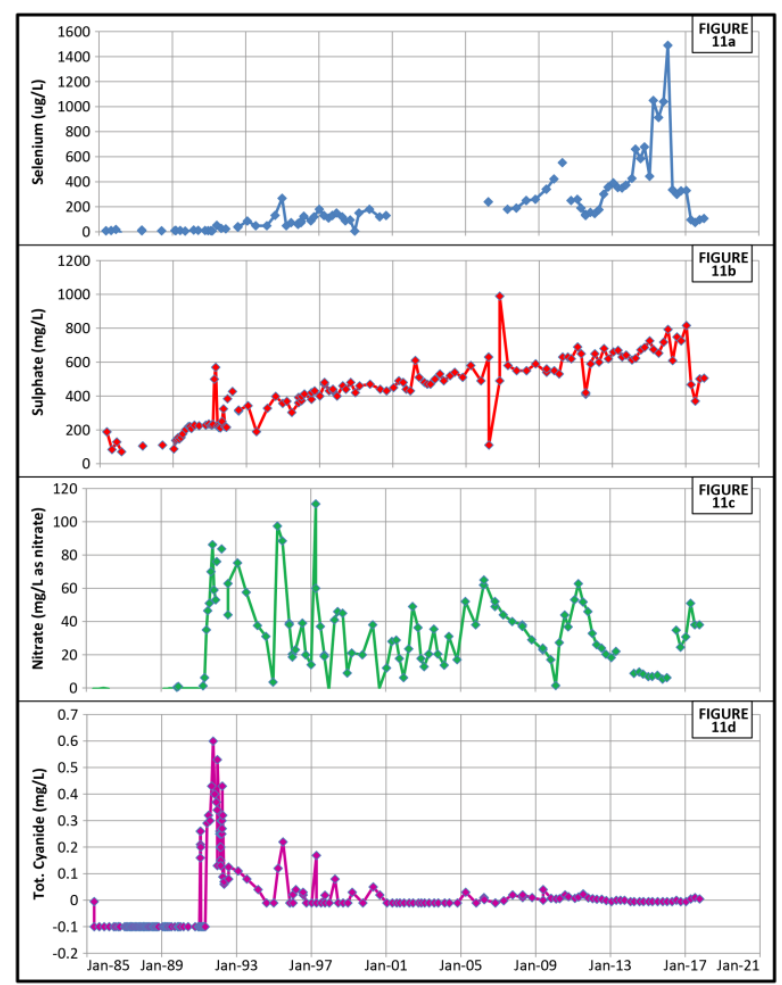

Figure 11(a)-(d) Trends in selenium, sulphate, nitrate and cyanide at Well \#M-1 
The investigation concluded that the selenium and other constituent increases were due to terminating operation of the leach pad LCSs, which occurred in 1991 once active leaching was stopped and rinsing was initiated. The corrective action was to re-initiate removal of the leachate from the LCSs in 1992.

As shown in Figure 11, the corrective action did very little to resolve the groundwater quality changes at M-1; selenium and sulphate concentrations continued to increase, nitrate concentrations fluctuated up and down, and cyanide was consistently detected (although concentrations were decreasing) through 1993 with occasional small concentration spikes thereafter.

Follow-up evaluations confirmed that the source of cyanide in the groundwater was related to its only presumed source (leakage from the leach pad), and degradation and corrective measures mitigated the cyanide impacts. The cyanide source of nitrate reduced as cyanide was mitigated, but the blasting source of nitrate, which affects both waste rock pile and heap leach pad leachate, persists. The sulphate comes from sulphide oxidation in both the waste rock and the heap leach pads, and mass balance calculations predict that it will remain a persistent source for many decades.

However, the evaluations demonstrated that the selenium at M-1 was not due to a mine waste or water source. The highest selenium concentrations in the heap leach water never exceeded $100 \mu \mathrm{g} / \mathrm{L}$ and have remained in the range of typically 30 to $60 \mu \mathrm{g} / \mathrm{L}$. All the monitoring data in the database for waste rock leachate indicated selenium concentrations were less than half the concentration in the heap leach pad (generally $20 \mu \mathrm{g} / \mathrm{L}$ or less).

Figure 11(a) indicates several instances where selenium rose quite sharply, first to over $200 \mu \mathrm{g} / \mathrm{L}$ in December 1994, second to $634 \mathrm{ug} / \mathrm{L}$ in February 2010, and then to the overall peak concentration of nearly $1,500 \mathrm{ug} / \mathrm{L}$ in January 2016. The other constituents did not exhibit these peaks in concentration. The first two peaks occurred at approximately the same time as extreme wet years when groundwater levels were much higher than normal, so we postulated that perhaps the high selenium concentrations were due to a natural source in the unsaturated zone that was contributing the selenium. However, the very high peak concentration near $1,500 \mu \mathrm{g} / \mathrm{L}$ in 2016 actually occurred during the last year of a multi-year draught and groundwater levels were low. Therefore, the elevated concentration of selenium at M-1 is not related to either high or low groundwater levels.

There are currently two alternative hypotheses for the increase in selenium at M-1. The first is that changes in physical stresses on the slope where M-1 is located have opened up new fractures near the well or within the borehole that expose fresh mineral surfaces that release selenium under natural mineral weathering and oxidation processes. The changes to physical stresses resulted from placement of the large mass of waste rock and ore residue at the top of the very steep slope where M-1 is located. The second hypothesis is that there is a vein or mineral deposit within or intersected by the well bore that is weathering at a variable rate. Developing further evidence supporting either of these alternative hypotheses would be expensive and may not be productive.

Fortunately, the existing evidence (principally a concentration peak that is orders of magnitude higher than any other measurements at the site) was sufficient for the regulatory agency to support that the selenium is not from a release of waste and is due to a unique, natural condition. At this point, with the regulatory agency support, the solution for selenium at $\mathrm{M}-1$ is to eliminate selenium from the monitoring program based on detailed evaluation of 25 years of monitoring data.

\section{Discussion}

The case studies presented in this paper were selected from dozens of instances at these two mine sites where water quality changes were likely caused by construction of the mine or mining facilities. In the authors' collective experience, there are instances where water quality changes are clearly due to releases of mine waste or mine water, but it is often the case that surface and groundwater quality changes at mines can be attributed to these other mechanisms. 
The complex and lengthy closure process for both of these mines may have been simplified and shortened if there were additional information presented in the original environmental authorisations (i.e. environmental impact assessments) for these mines. Based on our experience, we recommend the following additional data and technical evaluations as part of the initial environmental approvals, some of which are not new but we list here for emphasis based on the examples presented above, and others that are not commonly found in baseline technical studies.

\subsection{Develop a comprehensive baseline water quality dataset}

There are numerous examples throughout the world in mining and other industries where remediation, closure, and reclamation would have been simpler if the baseline conditions had been better characterised. Baseline groundwater quality and flow conditions for the first of the two mines described in this paper were established using 13 wells covering the 1,380 ha of mine pits, waste rock piles, tailings impoundments, process ponds, roads, and milling and beneficiation facilities. These wells were tested for a limited list of parameters over six quarterly monitoring events. The range in TDS concentrations alone covered two orders of magnitude in this baseline dataset, and better definition (higher density of sampling locations) would have been beneficial to the closure process. Groundwater elevations and their temporal variation, locations of seeps and springs, and hydrogeologic parameters (hydraulic conductivity, storage, structural controls on groundwater flow, etc.) were not characterised at all as part of the baseline studies.

Baseline conditions at the second mine described above were based on testing at nine monitoring wells covering an area of approximately 120 ha where most of the waste rock piles and all the heap leach pads were constructed, with no characterisation for the remaining 370 ha of the mine and other mining facilities. The temporal coverage of the baseline dataset was also limited at this mine, with only three sampling events during a one-year period. The list of parameters in the baseline dataset was even more limited, with only TDS, sulphate, nitrate, and a short list of metals being tested.

It is currently more the rule than the exception for proposed projects in North America to collect at least two years of quarterly testing with a very long list of geochemical and inorganic parameters being analysed as well as water levels and flows. However, it is often the case that lateral and vertical coverage of testing locations is very limited (e.g. one well per 50 to 100 ha) and there is little characterisation of hydrogeologic conditions and parameters. Because mine plans and conditions typically change from what was originally envisioned, spatial coverage that appears excessive and expensive during the baseline characterisation stage of a project is often paid for many times over during the operations and closure phases because of the weight of evidence of these types of data in evaluation of impacts.

A minimum of two years of quarterly data with a long list of geochemical and inorganic characterisation parameters is recommended for the baseline period. Additionally, detailed characterisation of groundwater levels, flow and direction; hydrogeologic conditions and parameters; and seasonal surveys of seeps and springs with water quality and flow testing should be performed during this period. Continued quarterly monitoring of selected parameters of concern should be performed throughout the project development and construction period as these data can also be included or considered for the baseline characterisation.

\subsection{Establish baseline 'values' of site water resources}

The environmental value of the site water resources should be established and documented during initial environmental authorisations. The baseline environmental value of water resources is established by applying human health and ecological environmental risk assessment methods to establish what potential beneficial uses (e.g. drinking water, industrial supply, cold or warm aquatic habitat, etc.) may be applicable for surface and groundwater at the mine site and where these conditions occur. The exposure scenarios evaluated should represent the entire range of conditions over a mine property. 


\subsection{Evaluation of weathering processes as part of baseline geochemical characterisation}

Baseline geochemical characterisation at mines is typically focused on establishing the potential for acid rock drainage and metals leaching (ARD/ML). At both the subject mines in this paper, the potential for ARD/ML was well-characterised to establish that all the mined materials were non-acid generating and metals leaching potential was low. However, the static testing methods used in the assessment are not suitable for characterisation of the potential for constituents that would leach from in situ rock as a result of weathering reactions in the long term, and failed to identify the key constituents that would represent a water quality issue at the two sites (principally TDS and sulphate).

Kinetic tests such as long-term field cell tests are a good way to characterise the effects of weathering. Field cell tests and other kinetic tests that can be helpful in establishing the effects of weathering in the long term are described in many guidance documents for geochemical characterisation (e.g. Price 2009). Kinetic tests such as field cells should be initiated early in the baseline study period and continued throughout the baseline, construction, and operational periods of the mine. The composition and evolution of the leachate from the test provides an early indication of the parameters of concern for monitoring at the mine.

\subsection{Evaluation of geotechnical and rock mechanic data as part of environmental characterisation}

Geotechnical conditions and rock mechanics are considered throughout mine planning and construction, but the principal focus is on slope stability and foundation design with goals of safety and structural integrity. The mechanical stresses introduced by excavating a mine pit or construction of massive piles (waste rock, tailings, etc.) can cause fractures in rock that, while they may not compromise slope stability or foundation integrity, could potentially expose fresh mineral surfaces and/or alter the direction and magnitude of groundwater flow. Characterising the potential for such fracturing, even if just qualitatively, in baseline technical studies and initial environmental authorisations lays essential groundwork for studies that will inevitably be required when water quality or flow conditions change at a mine.

\section{Conclusion}

As mentioned in the introduction to this paper, the default position of regulators when water quality changes at a mine is that there has been a release of pollution, but at mines such changes can often be the result of redistribution of natural conditions caused by construction and operation of the mine or mine facilities. In addition to releases of mine waste or mine water, the types of activities that could change water quality include:

- Mine dewatering causing a change in groundwater elevation and/or flow direction.

- Construction of large lined areas that alters recharge patterns.

- Diversion of watercourses or removal of waterbodies that alters the volume and chemistry of recharge water.

- Creating fresh mineralised surfaces by drilling a monitoring well or inducing bedrock fractures by increasing mechanical stress.

If these types of activities are characterised as quantitatively as possible in baseline technical studies, closure plans and impact significance determinations that are part of initial environmental authorisations, such as environmental impact statements, then when the changes actually occur, there is documentation that the potential issues were understood, acknowledged and approved by stakeholders whose involvement continues through operations and closure. In the case studies presented in this paper, the regulator was a key stakeholder in the environmental approvals. Upfront acceptance by the regulator that the construction of the mine pit and tailings impoundment could cause a redistribution of the naturally poor-quality groundwater, or enhance or slow natural geochemical reactions in the native rock, would have 
set the stage for a more streamlined and efficient closure process. Even if releases of mine waste and water have been controlled, conditions at mine closure will be specifically different from pre-mine baseline. However, the post-closure conditions may not be different from baseline from the standpoint of environmental values and the overall condition.

\section{References}

Posey, HH, Renkin, ML \& Woodling, J, 2000, 'Natural acid drainage in the Upper Alamosa River of Colorado', Proceedings of the Fifth International Conference on Acid Rock Drainage, vol. 1, Society for Mining, Metallurgy and Exploration, Englewood, pp. 485-498.

Price, WA 2009, Prediction Manual for Drainage Chemistry from Sulphidic Geologic Materials, MEND Report 1.20.1, CANMET, Smithers.

Runnells, DD, Shepard, TA \& Angino, EE 1992, 'Determining natural background concentrations in mineralized areas', Environmental Science and Technology, vol. 26, pp. 2316-2322.

Sassoon, M 2008, Guidance Notes for the Implementation of Financial Surety for Mine Closure, The World Bank Group, Washington DC. 
